Природа Черкащини: стан, проблеми ращіонального природокористування та охорони в контексті виживання. (1996). Миколаїв: АТ “СІМАО”, Одеса: ОКСDА, 396 с.

Пятниџкий, С. С. (1961). Практикум по лесной селекџии. Москва: Сельхоз. лит., журн. и плакаты, 148 с.

Торчик, В. И., Холопук, Г. А., Келько, А. Ф. (2018). Перспективы интродукџии гинкго двулопастного (Ginkgo biloba L.) в Беларуси. Весиі Нацыянальнай акадэміі навук Беларусі. Серыя біялагічных навук. T. 63, № 1. С. 27-32.

сDизико-географический атлас мира. (1964). Москва: Академия наук СССР и главное управление геодезии и картографии ГГК СССР, 298 с.

Џибровська, Н. В. (2019). Liriodendron tulipifera L. у Правобережному Лісостепу України (біологія, екологія, інтродукщія, культивування): монографія. Київ: Паливода А. В., С. 107-115.

Шумик, М. І., Клюєнко, О. В., Коркуленко, О. М., Попіль, Н. І., Остап'юк, В. М. (2018). Онтоморфогенез літньозелених (листопадних) видів роду Rhododendron L. ex situ. Інтродукція рослин. № 3. С. 39-51.

УДК 581.331.2:582.973

DOI 10.37555/2707-3114.1.2021.247735

\title{
Morphology of pollen grains of Weigela floribunda (Caprifoliaceae): application in taxonomy
}

Tsymbalyuk Z. M., Nitsenko L. M., Mosyakin S. L.

M. G. Kholodny Institute of Botany, National Academy of Sciences of Ukraine, 2, Tereshchenkivska St., Kyiv 01004, Ukraine,

e-mail: palynology@ukr.net,necik@ukr.net,s_mosyakin@hotmail.com

\section{Морфологія пилкових зерен Weigela floribunda (Caprifoliaceae): використання у таксономії}

Џимбалюк 3. М., Ниџенко Л. М., Мосякін С. А.

Інститут ботаніки ім. М. Г. Холодного НАН України вул. Терешенківська, 2, Київ 01004, Україна, e-mail: palynology@ukr.net, necik@ukr.net, s_mosyakin@hotmail.com

Abstract. The aim of this research was to provide detailed quantitative and qualitative characteristics on pollen grains of Weigela floribunda (Siebold \& Zucc.) K. Koch (Caprifoliaceae) as applied for taxonomy. Pollen morphology of W. floribunda was studied using both light microscopy and scanning electron microscopy. Pollen grains are 3-porate, rarely 4 -porate, suboblate to spheroidal $(\mathrm{P} / \mathrm{E}=0.80-1.05)$; in equatorial view elliptic or circular, in polar view circular or subcircular; medium- or large-sized $(\mathrm{P}=42.56-61.18 \mu \mathrm{m}, \mathrm{E}=42.56-66.50 \mu \mathrm{m})$. Pores are circular with distinct or indistinct margins and distinct annuli. Exine sculpture is echinate-microechinate-nanoechinate. Pollen grains of $W$. floribunda were analyzed for the first time in the present study.

Key words: palynomorphology, pollen type, exine sculpture, taxonomy.

Анотація. Метою дослідження було надати детальну кількісну та якісну характеристику пилкових зерен Weigela floribunda (Siebold \& Zucc.) K. Koch (Caprifoliaceae) для џілей систематики. Морфологію пилку W. floribunda вивчали за допомогою світлової та сканувальної електронної мікроскопіі. Пилкові зерна 3-порові, зрідка 4-порові, сплюшено-сфероїдальні або сфероїдальні (П/E=0.80-1.05) за формою; в обрисі з екватора еліптичні або округлі, в обрисі з полюса округлі; середніх або великих розмірів (П=42.56-61.18 мкм, $\mathrm{E}=42.56-66.50$ мкм). Пори округлі, з чіткими або нечіткими краями та чітким обідком. Скульптура екзини шипувато-шипикувато-наношипикувата. Пилкові зерна $W$. floribunda вперше проаналізовані у џьому дослідженні.

Ключові слова: паліноморфологія, тип пилку, скульптура екзини, таксономія 
Introduction. Recent molecular studies clarified considerably the phylogenetic relationships within the order Dipsacales (Bell et al., 2001; Donoghue et al., 2001; Zhang et al., 2003; Theis et al., 2008; Winkworth et al., 2008; Jacobs et al., 2011; Wang et al., 2015; Xiang et al., 2020). The family Caprifoliaceae s.l., as currently circumscribed in a wide sense, contains representatives of several other previously recognized families of Dipsacales, such as Valerianaceae, Dipsacaceae, Morinaceae, Diervillaceae, etc. (APG III, 2009; APG IV, 2016). According to new molecular phylogenetic data, the genus Weigela Thunb., together with the genus Diervilla Tourn. ex Mill., forms the clade of Diervilloideae, which is sister to the clade containing representatives of Caprifolioideae (Wang et al., 2021).

Weigela includes ca. 10 species native in North-Central, South-Central and Southeast China, with Inner Mongolia and Manchuria; Japan; Korea; Khabarovsk Region, Kuril Islands, Primorye, and Sakhalin of Russia (Barbarych, 1961; IPNI, 2021); the species W. floribunda (Siebold \& Zucc.) K. Koch grows in Japan. In Ukraine it is cultivated in gardens and parks as a popular ornamental shrub (Barbarych, 1961; Mosyakin, Fedoronchuk, 1999).

It is well known that morphological characters of pollen grains as additional diagnostic features are often efficiently used for taxonomy (Jacobs et al., 2011; Mosyakin, Tsymbalyuk, 2015, 2017; Tsymbalyuk et al., 2018, 2019a, b, 2020, 2021; Dirmenci et al., 2019, etc.). However, the available information about pollen grains of representatives of the genus Weigela is limited. Donoghue (1985) investigated pollen grains of W. florida (Bunge) A. DC. using both light microscopy and scanning electron microscopy. Jacobs et al. (2011) investigated pollen grains of three species (W. coraeensis Thunb., W. decora (Nakai) Nakai, W. Maximowiczii (S. Moore) Rehder of the genus Weigela using scanning electron microscopy; however, the photomicrographs are absent in that publication. The PalDat online database contains some information on pollen grains and photomicrographs of $W$. floribunda using light microscopy (Auer, 2021).

The aim of the present research was to provide detailed quantitative and qualitative characteristics of the pollen grains of $W$. floribunda and to evaluate the importance of these data for taxonomy.

Materials and methods. Pollen grains of W. floribunda were sampled at the National Herbarium of Ukraine (KW - Herbarium of the M. G. Kholodny Institute of Botany, National Academy of Sciences of Ukraine, Kyiv, Ukraine). Herbarium acronyms are given following Index Herbariorum (Thiers, 2008-onward, continuously updated). Abbreviations of names of taxon authors mainly follow Brummitt, Powell (1992), with additions and updates available from IPNI (2021).

In general, the methods used in the present study were the same as those we used earlier (Tsymbalyuk et al., 2020, 2021). Pollen grains were studied using both light microscopy (LM) and scanning electron microscopy (SEM). For LM studies (Biolar, $\times 700$ ), the pollen was acetolyzed following the method by Erdtman (1952), mounted on slides with glycerinated gelatin, and analyzed and photomicrographed using a light microscope. For size determinations, 30 measurements were taken along the polar axis $(P)$ and equatorial diameter $(E) ; 20$ measurements of the exine and annulus thickness, width and length of pores were performed. The $\mathrm{P} / \mathrm{E}$ ratio was calculated in order to determine the pollen shape. For all quantitative characters, descriptive statistics was applied and the range (minimum and maximum values), arithmetic mean and standard deviation were calculated. The number of echini/microechini/nanoechini per unit area $\left(100 \mu \mathrm{m}^{2}\right)$ was determined. The slides are deposited in the Palynotheca (reference pollen collection) at the National Herbarium of Ukraine (Bezusko, Tsymbalyuk, 2011).

For SEM (JEOL JSM-6060LA), dry pollen grains were treated with 96\%-ethanol, then samples were sputtercoated with gold and investigated at the Center of Electron Microscopy of the M. G. Kholodny Institute of Botany. The measurements of the echini, microechini and nanoechini were taken on five pollen grains from SEM micrographs and made using the program AxioVision Rel. 4.8.2. Terminology used in descriptions of pollen grains follows the glossaries by Punt et al. (2007) and Halbritter et al. (2018).

Results and discussion. The original data on quantitative pollen characters are summarized in Table. LM and SEM photomicrographs of pollen grains are shown in Figures 1 and 2. Description of pollen grains of W. floribunda.

LM. Pollen grains 3-porate, rarely 4-porate, suboblate to spheroidal, in equatorial view elliptic or circular, in polar view circular or subcircular. Pores circular, rarely elliptic, with distinct or indistinct margins, and distinct annuli, pore membrane psilate. Exine very thin, undifferentiated into layers. Columellae absent. Exine sculpture echinate-microechinate-nanoechinate. 
SEM. Exine sculpture echinate-microechinate-nanoechinate. Echini cylindrical, 1.32-2.64 $\mu \mathrm{m}$ high, 0.96-1.62 $\mu \mathrm{m}$ wide at base, with straight sides and acute apices, echini higher than basal width, $\left(2-5 / 100 \mu \mathrm{m}^{2}\right)$. Echini with convex sides, acute or obtuse apices, 1.02-1.61 $\mu \mathrm{m}$ high, 0.95-1.48 $\mu \mathrm{m}$ wide at base, echini higher than basal width, $\left(2-3 / 100 \mu \mathrm{m}^{2}\right)$; microechini with convex sides and obtuse apices, 0.76-0.82 $\mu \mathrm{m}$ high, 0.74-0.98 $\mu \mathrm{m}$ wide at base, about as broad as height $\left(3-5 / 100 \mu \mathrm{m}^{2}\right)$; nanoechini with convex sides and obtuse apices, 0.38-0.59 $\mu \mathrm{m}$ high, 0.67-0.81 $\mu \mathrm{m}$ wide at base, broader than high $\left(1-5 / 100 \mu \mathrm{m}^{2}\right)$; tectum psilate-granulate in area between echini. Pore membranes granulate.

Specimen investigated: Hort. Bot. Jurjevensis [now Tartu, Estonia]. Japonia (Culta) fl. 10.IV 1886. Teste: Prof. N. Kusnezow et F. F. Wagner (KW).

Table. Pollen morphometric characters: mean \pm standard deviation; range (min-max) (all measurements given as $\mu \mathrm{m}$ ).

\begin{tabular}{|l|l|}
\hline \multicolumn{1}{|c|}{ Characters } & \multicolumn{1}{c|}{ Measurements } \\
\hline Polar axis & $49.61 \pm 4.79(42.56-61.18)$ \\
\hline Equatorial diameter & $52.48 \pm 6.94(42.56-66.50)$ \\
\hline P/E ratio & $0.95 \pm 0.06(0.80-1.05)$ \\
\hline Pore length & $6.56 \pm 1.19(3.99-9.31)$ \\
\hline Pore width & $5.90 \pm 0.93(3.99-6.65)$ \\
\hline Annulus thickness & $2.33 \pm 0.50(1.33-3.32)$ \\
\hline Exine thickness & $1.22 \pm 0.32(0.66-1.99)$ \\
\hline
\end{tabular}

The obtained data demonstrated that pollen grains of $W$. floribunda have a porate type of apertures. A characteristic feature of pollen grains of this species is also a very thin exine undifferentiated into layers, as well as the absence of columellae. The exine sculpture is represented by echini of two types: (1) echini with a cylindrical, parallel-sided basal part with a conical acute apex; the basal part is normally longer than the apex, height of echini exceeding their basal width; and (2) echini with a more or less circular basal part, with an obtuse or rarely acute apex; height of echini exceeding their basal width. Microechini about as broad as high, nanoechini broader than high.

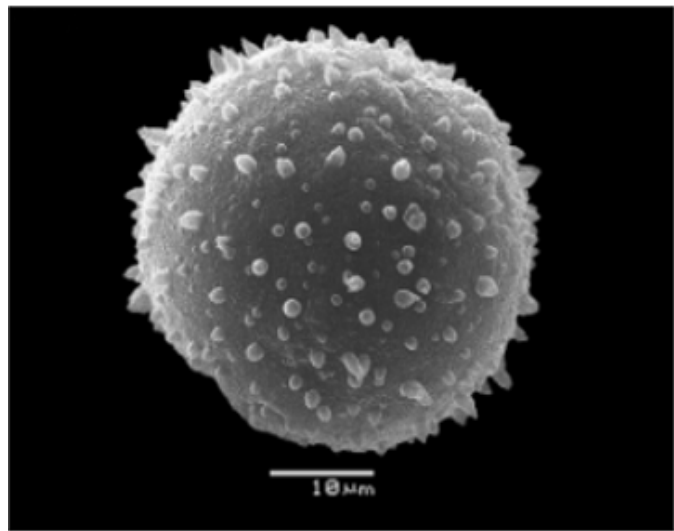

A

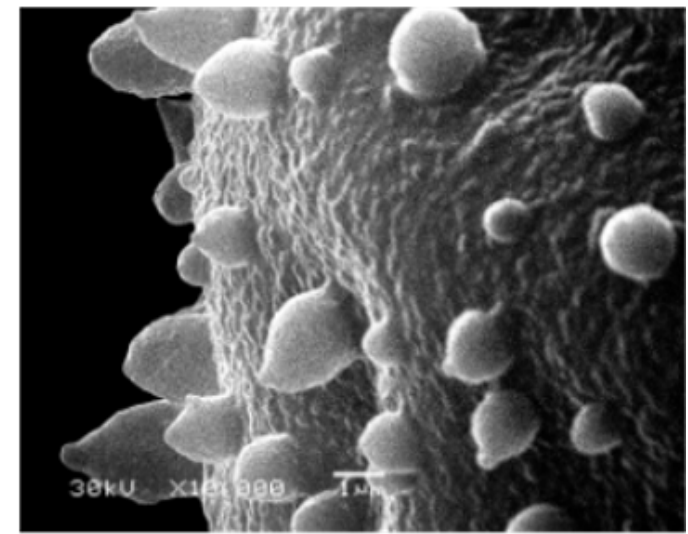

$\mathrm{B}$

Fig. 1. Pollen grains of W. floribunda (SEM): A - equatorial view, B - exine sculpture.

The pore type of apertures and echinate sculpture are characteristic of pollen grains of the genera Knautia L., Dipsacus L., Cephalaria Schrad. (Tsymbalyuk et al., 2018, 2019 a, b, 2020). However, pollen grains of W. floribunda are morphologically different from pollen grains of other studied species. The pollen characteristics described here may be used in future studies aiming at completing the knowledge on all Weigela species and at understanding the evolution of pollen morphology in Caprifoliaceae in general. 


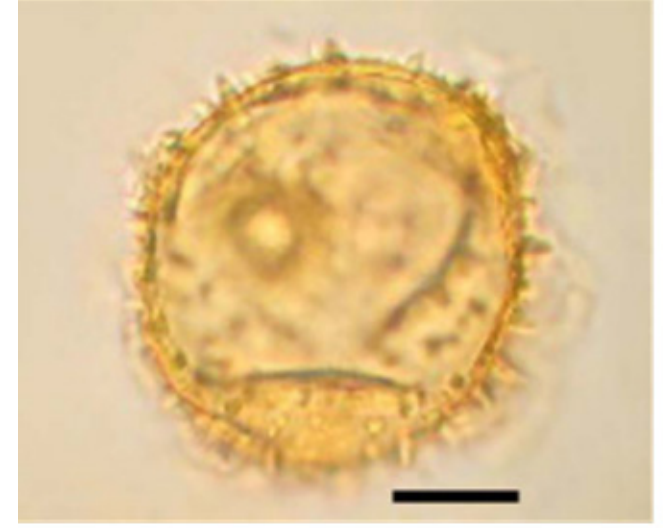

A

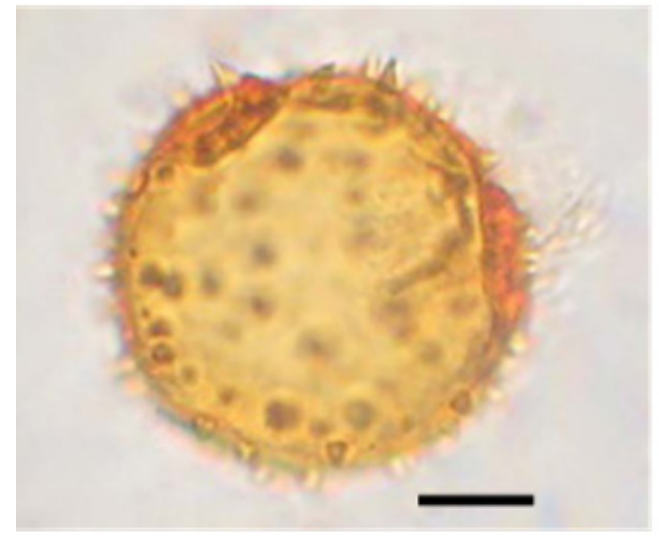

C

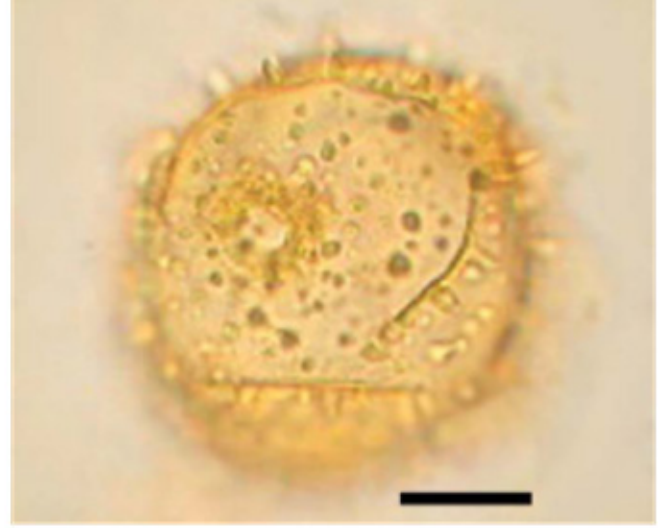

B

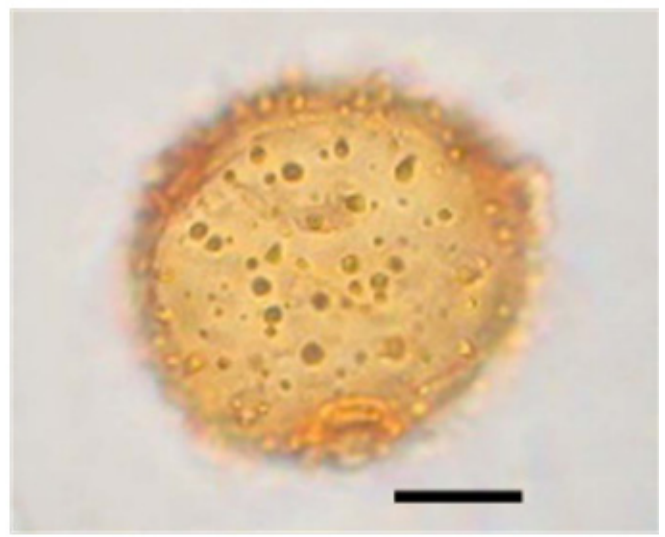

$\mathrm{D}$

Fig. 2. Pollen grains of W. floribunda (LM): A, B - equatorial view, C, D - polar view. Scale bars $=10 \mu \mathrm{m}$.

\section{Acknowledgements}

The authors express their gratitude to Natalia M. Shyian, Head Curator of the National Herbarium of Ukraine (KW; herbarium of the M. G. Kholodny Institute of Botany, National Academy of Sciences of Ukraine). Kind help and cooperation of Dmytro O. Klymchuk, Head of the Centre of Electron Microscopy (M. G. Kholodny Institute of Botany), is greatly appreciated.

\section{References}

APG III (2009). An update of the Angiosperm Phylogeny Group classification for the orders and families of flowering plants: The Angiosperm Phylogeny Group. Botanical Journal of the Linnean Society, 161 . P. 105-121. https://doi.org/10.1111/j.1095-8339.2009.00996.x.

APG IV (2016). An update of the Angiosperm Phylogeny Group classification for the orders and families of flowering plants: The Angiosperm Phylogeny Group. Botanical Journal of the Linnean Society, 181(1). P. 1-20. https://doi.org/10.1111/boj.12385.

Auer, W. (2021). Weigela floribunda. PalDat - A palynological database.

URL: https://www.paldat.org/pub/Weigela_floribunda/305529 (accessed 2021-07-21).

Barbarych, A. I. (1961). Weigela. In: Kotov, M. I. (ed.). Flora of the Ukrainian SSR [Flora URSR]. Vol. 10. Kyiv: Vyd-vo AN URSR. P. 286-288.

Bell, C. D., Edwards, E. J., Kim, S. T., Donoghue, M. J. (2001). Dipsacales phylogeny based on chloroplast DNA sequences. Harvard Papers in Botany, 6(2). P. 481-499. https://www.jstor.org/stable/41761758.

Bezusko, L. G., Tsymbalyuk, Z. M. (2011). Palynotheca of the M. G. Kholodny Institute of Botany, National Academy of Sciences of Ukraine. In: Shiyan, N. M. (ed.). Herbaria of Ukraine. Index Herbariorum Ucrainicum. Kyiv: Alterpress. P. 138-141. 
Brummitt, R. K., Powell, C. E. (eds) (1992). Authors of plant names. A list of authors of scientific names of plants, with recommended standard forms of their names, including abbreviations. Kew: Royal Botanic Gardens. 732 p. ISBN10:0947643443.

Dirmenci, T., Özcan, T., Arabaci, T., Çelenk, S., İsmailova, G. et al. (2019). Hybridization among three Cirsium (Asteraceae) species and important evidence for three new hybrids from Turkey. Turkish Journal of Botany, 43. P. 366-385.

Donoghue, M.J.(1985). Pollen diversity and exine evolution in Viburnum and the Caprifoliaceae sensu lato. Journal of the Arnold Arboretum, 66. P. 421-469.

Donoghue, M. J., Eriksson, T., Reeves, P. A., Olmstead, R. G. (2001). Phylogeny and phylogenetic taxonomy of Dipsacales, with special reference to Sinadoxa and Tetradoxa (Adoxaceae). Harvard Papers in Botany, 6(2). P. 459-479.

Erdtman, G. (1952). Pollen morphology and plant taxonomy. Angiosperms. Stockholm: Almqvist \& Wiksell. xii +539 p.

https://doi.org/10.1080/11035895209453507.

Halbritter, H., Ulrich, S., Grímsson, F., Weber, M., Zetter, R. et al. (2018). Illustrated Pollen Terminology. Ed. 2. Cham: Springer International Publishing. xviii + 501 p. https://doi.org/10.1007/978-3-319-71365-6.

IPNI (2021 -onward). International Plant Names Index. The Royal Botanic Gardens, Kew, Harvard University Herbaria \& Libraries and Australian National Botanic Gardens. URL: http:/ /www.ipni.org (accessed 09 August 2021).

Jacobs, B., Geuten, K., Pyck, N., Huysmans, S., Jansen, S. et al. (2011). Unraveling the phylogeny of Heptacodium and Zabelia (Caprifoliaceae): An interdisciplinary approach. Systematic Botany, 36(1). P. 231-252.

http://www.bioone.org/doi/full/10.1600/036364411X553306.

Mosyakin, S. L., Fedoronchuk, M. M. (1999). Vascular plants of Ukraine. A nomenclatural checklist. Kiev. xxiii +345 p.

Mosyakin, S. L. Tsymbalyuk, Z. M. (2015). Pollen morphology of the tribes Aptosimeae and Myoporeae supports the phylogenetic pattern in early-branching Scrophulariaceae revealed by molecular studies. Willdenowia, 45(2). P. 209-222.

https://doi.org/10.3372/wi.45.45207.

Mosyakin, S. L., Tsymbalyuk, Z. M. (2017). Pollen morphology of the tribe Hemimerideae: possible evidence of ancestral pollen types and parallel evolution in the basalmost clade of Scrophulariaceae s. str. Willdenowia, 47. P. 15-27. https://doi.org/10.3372/wi.47.47102.

Punt, W., Hoen, P. P., Blackmore, S., Nilsson, S., Le Thomas, A. (2007). Glossary of pollen and spore terminology. Review of Palaeobotany and Palynology, 143. P. 1-81. http://dx.doi.org/10.1016/j.revpalbo.2006.06.008.

Theis, N., Donoghue, M. J., Li, J. (2008). Phylogenetics of the Caprifolieae and Lonicera (Dipsacales) based on nuclear and chloroplast DNA sequences. Systematic Botany, 33(4). P. 776-783. https://doi. org/10.1600/036364408786500163.

Thiers, B. (2008-onward, continuously updated). Index Herbariorum. A global directory of public herbaria and associated staff. New York Botanical Garden\&apos; s Virtual Herbarium. URL: http:/ /sweetgum.nybg.org/ science/ih/ (accessed 09 August 2021).

Tsymbalyuk, Z. M., Bezusko, L. G., Mosyakin, S. L., Nitsenko, L. M. (2019a). Pollen morphology of species of Dipsacus (Dipsacaceae) in the flora of Ukraine: significance for taxonomy and spore-pollen analysis. Ukrainian Botanical Journal, 76(1). P. 9-23. https://doi.org/10.15407/ukrbotj76.01.009.

Tsymbalyuk, Z. M., Bezusko, L. G., Nitsenko, L. M. (2018). Pollen morphology of species of the genus Knautia (Dipsacaceae) in Ukraine: an assessment for taxonomy and spore-pollen analysis. Ukrainian Botanical Journal, 7(3). P. 248-259. https://doi.org/10.15407/ukrbotj75.03.248.

Tsymbalyuk, Z. M., Çelenk, S., Mosyakin, S. L., Nitsenko, L. M. (2020). Pollen morphology of some species of the genus Cephalaria Schrad. (Caprifoliaceae) and its significance for taxonomy. Microscopy Research \& Technique, 84(2). P. 1-13. https://doi.org/10.1002/jemt.23627. 
Tsymbalyuk, Z. M., Ivanova, D., Nitsenko, L. M. (2021). Taxonomic significance of palynomorphological characteristics of selected Centranthus (Caprifoliaceae) species. Hacquetia, 20(2). P. 243-256. https://doi. org/10.2478/hacq-2020-0021.

Tsymbalyuk, Z. M., Mosyakin, S. L., Nitsenko, L. M. (2019b). Taxonomic significance of pollen morphology in Succisa and Succisella. Biodiversity Research and Conservation, 55(1). P. 1-6.https://doi.org/10.2478/ biorc-2019-0010.

Wang, H. F., Landrein, S., Dong, W. P., Nie, Z. L., Kondo, K. et al. (2015). Molecular phylogeny and biogeographic diversification of Linnaeoideae (Caprifoliaceae s.l.) disjunctly distributed in Eurasia, North America and Mexico. PLoS ONE, 10(3). P. e0116485. https://doi.org/10.1371/journal.pone.0116485.

Wang, H. X., Morales-Briones, D. F., Moore, M. J., Wen, J., Wang, H. F. (2021). A phylogenomic perspective on gene tree conflict and character evolution in Caprifoliaceae using target enrichment data, with Zabelioideae recognized as a new subfamily. Journal of Systematics and Evolution. 00(0). P. 1-18. https://doi.org/10.1111/ jse. 12745 .

Winkworth, R. C., Bell, C. D., Donoghue, M. J. (2008). Mitochondrial sequence data and Dipsacales phylogeny: Mixed models, partitioned Bayesian analyses, and model selection. Molecular Phylogenetics and Evolution, 46(3). P. 830-843. https://doi.org/10.1016/j.ympev.2007.11.021.

Xiang, C. L., Dong, H. J., Landrein, S., Zhao, F., Yu, W. B. et al. (2020). Revisiting the phylogeny of Dipsacales: New insights from phylogenomic analyses of complete plastomic sequences. Journal of Systematics and Evolution, 58(2). P. 103-117. https://doi.org/10.1111/jse.12526.

Zhang, W. H., Chen, Z. D., Li, J. H., Chen, H. B., Tang, Y. C. (2003). Phylogeny of the Dipsacales s.l. based on chloroplast trnL-F and ndhF sequences. Molecular Phylogenetics and Evolution, 26(2). P. 176-189. https://doi.org/10.1016/S1055-7903(02)00303-2. 